\title{
Prevalence of Anticardiolipin Antibodies in Pregnancies with History of Repeated Miscarriages
}

\author{
Ligia Cosentino Junqueira Franco Spegiorin ${ }^{1}$, Eloísa A Galão ${ }^{1}$, Lúcia Buchalla Bagarelli ${ }^{1}$, \\ Antonio Hélio Oliani ${ }^{1}$ and José Maria Pereira de Godoy ${ }^{*}$
}

\author{
${ }^{I}$ Department of Gynecology of São José do Rio Preto Medicine School of São Paulo (FAMERP), Brazil \\ ${ }^{2}$ Department of Cardiology and Cardiovascular Surgery in Medicine School of São José do Rio Preto and CNPq \\ (National Council for Research and Development), Brazil
}

\begin{abstract}
Aim: This study aimed at evaluating the prevalence of high anticardiolipin antibody and lupus anticoagulant levels in women with histories of at least two miscarriages.

Methods: The presence of high anticardiolipin antibody and lupus anticoagulant levels were evaluated in 52 patients with ages between 17 and 41 (mean 26.7 years old) who had histories of repeated miscarriages.

Results: High anticardiolipin antibody levels were identified in $55.77 \%$ and lupus anticoagulant levels in $2 \%$ of the individuals.

Conclusion: In conclusion, women who suffer from repeated miscarriages present with a high prevalence of anticardiolipin antibodies. Further studies on this issue are crucial as these antibodies are associated with hypercoagulability and thus increased the risk of thromboembolic events.
\end{abstract}

Keywords: Repetitive miscarriage, thromboembolism, anticardiolipin antibodies, lupus, anticoagulant.

\section{INTRODUCTION}

Antiphospholipid syndrome (APS), in relation to pregnancy, is characterized by the presence of antiphospholipid autoantibodies in association with repeated fetal loss and complications such as pre-eclampsia, retarded fetal growth or placental insufficiency [1,2]. This syndrome constitutes a heterogeneous group of circulating antibodies against anionic phospholipids with the most important ones being Anticardiolipin Antibodies (ACA), a positive Venereal Disease Research Laboratory test (VDRL) and lupus anticoagulants $[2,3]$. False-positive VDRL results do not constitute diagnostic criteria for the syndrome due to the low sensitivity and specificity of the test. However, high levels in pregnant women should serve as a warning of the presence of antiphospholipid antibodies [4].

In pregnant women, an APS rate from $0.2 \%$ to $2 \%$ is similar to the frequency in the general population [5], however, this syndrome is responsible for about $10 \%$ of the cases of repeated miscarriages $[6,7]$.

Several publications have associated APS with retarded intrauterine growth $[8,9]$ and others with pre-eclampsia $[5$, 10] although this latter correlation remains controversial [11, 12].

*Address correspondence to this author at the Department of Cardiology and Cardiovascular Surgery in Medicine School of São José do Rio Preto and $\mathrm{CNPq}$ (National Council for Research and Development), Rua Floriano Peixoto, 2950, São José do Rio Preto, Zipe Code: 15010-020, SP, Brazil; Tel: 5517 32326362; E-mail: godoyjmp@riopreto.com.br
Antibodies of this syndrome can inhibit placental anticoagulant protein by binding to phospholipids, thereby leading to thrombosis [13], and also by influencing the production of gonadotropin [14]. The $\beta 2$ glycoproteins act as a cofactor in the binding of antiphospholipid antibodies to anionic phospholipids, thus functioning as a natural anticoagulant and therefore any interference in this system may result in thrombosis [15]. In an animal model, spontaneous miscarriages were observed with passive transfer of purified anticardiolipin $\operatorname{IgG}[1,16]$.

Treatment using heparin, aspirin or intravenous immunoglobulins reduces the rate of fetal loss. Risk of preeclampsia and placental insufficiency occurs in around 50\% of non-treated patients and the success rate of prophylactic treatment using heparin and aspirin is approximately $70 \%$ [1]. The reduction of these symptoms with the normalization of the levels of ACA is associated to an improvement in the survival rate of fetuses during pregnancy [17].

This current study aimed at evaluating the prevalence of high ACA and lupus anticoagulant levels in women who had suffered two or more miscarriages.

\section{METHODS}

In a retrospective study, 52 consecutive pregnant women who had suffered from two or more miscarriages were evaluated in a teaching hospital in São José do Rio Preto, São Paulo, Brazil, in a period from April 1988 to November 2003. Their ages ranged from 17 to 41 years old with a mean of 26.7 years. Inclusion criteria were a history of multiple miscarriages ( 2 or more) and positive results for ACA tests. 
No patient had a history of rheumatologic disease before pregnancy. Patients who suffered not more than one miscarriage were excluded from the study. Evaluation of the ACA was achieved by Enzyme-Linked Immunosorbent Assay (ELISA - Quanta Lite ${ }^{\text {TM }}$ ACA IgG/IgM INOVA Diagnostics). Lupus anticoagulant was investigated using the activated partial thromboplastin time (aPTT) prolonged by the presence of an inhibitor. For statistical analysis, simple percentages and the Fisher exact test were utilized with an alpha error of $5 \%$ (p-value $<0.05)$ were considered acceptable.

The study was approved by the Ethics Committee of the Medical School in São Jose do Rio Preto, Brazil (FAMERP).

\section{RESULTS}

Abnormally high ACA levels were detected in $55.77 \%$ of the women and lupus anticoagulant in $2 \%$.

High IgM ACA levels were found in $41.1 \%$ of the cases, high IgG ACA in $17.6 \%$ and high levels for both IgM and IgG ACA were identified in $38.2 \%$ of the cases. There was no significant difference between the number of patients with high IgG and IgM immunoglobulin levels when analyzed using the Fisher exact test (p-value $<0.09$ ).

\section{DISCUSSION}

High ACA levels are harmful to the normal evolution of gestation and can affect both mother and child. Diagnosis and prophylactic treatment can improve the outcome of the pregnancy $[1,18]$. The current study detected an abnormally high rate of pregnant women who had suffered repeated miscarriages with high serum levels of these antibodies. The prevalence of lupus anticoagulant $(2 \%)$ was lower than the rate of ACA (55.7\%). Thus, it is important to highlight this high prevalence as venous thromboembolism has been identified as one of the commonest causes of maternal death $[19,20]$. This should be seen as a warning about the necessity to investigate hypercoagulability states during pregnancy particularly in respect to antiphospholipid antibodies. We should continue to be aware of maternal complications other than miscarriages. Some published investigations did not identify any association between antiphospholipid antibodies and repeated miscarriages [21, $22]$, but other studies did [23, 24]. This demonstrates the need for further studies using larger number of individual and standardization of the investigational methods. Gestation and puerperium are associated with thromboembolism [25, 26], thus an association of risk factors in maternal thromboembolism is implicated.

In the evolution of these patients it is observed that the ACA levels may vary, and even may become negative. In this group, three patients had a history of thrombotic events; two deep venous thrombosis and one myocardial infarction. Thrombotic events are associated with the syndrome and physicians should be watchful about this possibility.

The prevalence of patients with high levels of these antibodies in the current study is within the range cited by other studies, as publications have reported a prevalence of these antibodies in from 15 to $59.1 \%$ of cases [26-28]. This variation is due to the different methods employed to measure the antibodies and so there is a true necessity of standardization.

Another warning is related to the possibility of falsepositive VDRL results and their interpretation that can cause psychological instability within the family [29].

\section{CONCLUSION}

In conclusion, individuals suffering from repeated miscarriages are frequently present with antiphospholipid antibody syndrome. These data indicate the necessity of a systemic investigation of these antibodies in pregnant women.

\section{COMPETING INTERESTS}

The authors declare that they have no competing interests (political, personal, religious, ideological, academic, intellectual, commercial or any other) in relation to this manuscript.

\section{REFERENCES}

[1] Heilmann L, von Tempelhoff GF, Pollow K. Antiphospholipid syndrome in obstetrics. Clin Appl Thromb Hemost 2003; 9(2): 14350 .

[2] Wendell AW, Ghavari AE, Koike T, et al. International consensus statement on preliminary classification for definitive antiphospholipid syndrome. Arthritis Rheum 1999; 42: 1309-11.

[3] de Godoy JM, de Godoy MF, Braile DM, Torres CA. Prevalence of anticardiolipin antibodies in peripheral arterial thrombosis. Angiology 2000; 51(6): 473-7.

[4] Gutierrez M, Scopeletis E, Cabrera G, et al. Anticardiolipin Antibodies Syndrome: pathological considerations. Rev Bras Reumatol 1993; 33: 101-6.

[5] Branch DW, Dudlwy DJ, Scott IR, Silver JM. Antiphospholipid antibodies and fetal loss. N Engl J Med 1992; 326: 951-2.

[6] Love PE, Santoro SA. Antiphospholipid antibodies: anticardiolipin and lupus anticoagulant in systemic lupus erythematosus (SLE) and in non-SLE disorders; prevalence and clinical. Ann Intern Med 1990; 112: 682-98.

[7] Cowchock S. The role of antiphospholipid antibodies in obstetric medicine. Curr Obstet Med 1991; 1: 229-47.

[8] Nilsson IM, Asted B, Hedner V, Berezin D. Intrauterine death and circulating anticoagulant (antithromboplastin). Acta Med 1975; 197: 153-9.

[9] Lockshin M D, Druzin M L, Goei S, et al. Antibody to cardiolipin as a predictor of fetal distress or death in pregnant patients with systemic Lupus Erythematosus. N Eng J Med 1985; 18: 152-6.

[10] Silver RM, Porter TF, van Levween I, Jeng G, Scott JR, Branch DW. Anticardiolipin antibodies: clinical consequences of "low titer". Obstet Gynecol 1996; 87: 494-500.

[11] Out HJ, Bruinse HW, Christianes GC, et al. A prospective controlled multicenter study on the obstetric risks of pregnant women with antiphospholipid antibodies. Am J Obstet Gynecol 1992; 167: 26-32.

[12] Stuart RA, Kormann LH, Mc Hugh NJ. A prospective study of pregnancy outcome in women screened at a routine antenatal clinic for anticardiolipin antibodies. Br J Obstet Gynaecol 1993; 100: 599-600.

[13] Sammaritano LR, Gharavi AE, Soberano C, Levy RA, Lockshin MD. Phospholipid binding of antiphospholipid antibodies and placental anticoagulant protein. J Clin Immunol 1992; 12: 27-35.

[14] Di Simone N, Meroni PL, de Papa N, et al. Antiphospholipid antibodies affect trophoblast gonadotropin secretion and invasiveness by binding directly and through adhered beta2glycoprotein I. Arthritis Rheum 2000; 43(1): 140-50.

[15] C Bu, C Zhang, Z Li, Gao L, Xie Z, Cai G. Autoantibodies to plasminogen and tissue plasminogen activator in women with recurrent pregnancy loss. Clin Exp Immunol 2007; 149(1): 31-9.

[16] Bakimer R, Fishman P, Blank M, Sredni B, Djaldetti M, Shoenfeld $\mathrm{Y}$. Induction of primary antiphospholipid syndrome in mice by 
immunization with a human monoclonal anticardiolipin antibody. $\mathrm{J}$ Clin Invest 1992; 89: 1558-63.

[17] Salazar-Paramo M, Jara LJ, Ramos A, Barile L, Machado G, García-De La Torre I. Longitudinal study of antinuclear and anticardiolipin antibodies in pregnant women with systemic lupus erythematosus and antiphospholipid syndrome. Rheumatol Int 2002; 22(4): 142-7.

[18] Vials JM. A literature review on the antiphospholipid syndrome and the effect on childbearing. Midwifery 2001; 17(2): 142-9.

[19] Department of Health, Welsh Office, Scottish Home and Health Department of Health and Social Services, Northern Ireland. Confidential Enquiries into Maternal Deaths in United Kingdom, 1991-1993. London: HMSO, 1996.

[20] The ministry of Welfare, Children and Families Bureau Maternal and Child Heath Division Maternal and Child Heath Statistic of Japan Tokyo: The Ministry of Welfore, 1999, pp. 76-8.

[21] Branch DW, Silver R, Pierangeli S, Van Leeuwen I, Harris N. Antiphospholipid antibodies other than lupus anticoagulant and Anticardiolipin antibodies in women with recurrent pregnancy loss, fertile controls, and Antiphospholipid syndrome. Obstet Gynecol 1997; 89: 549-55.

[22] Simpson JL, Carson SA, Chesney C, et al. Lack of association between antiphospholipid antibodies and first-trimester spontaneous abortion: prospective study of pregnancies detected within 21 days of conception. Fertil Steril 1998; 69(5): 814-20.
[23] Ogishima D, Matsumoto T, Nakamura Y, Yoshida K, Kuwabara Y. Placental pathology in systemic lupus erythematosus with antiphospholipid antibodies. Pathol Int 2000; 50(3): 224-9.

[24] Mello G, Parretti E, Martini E, et al. Usefulness of screening for congenital or acquired hemostatic abnormalities in women with previous complicated pregnancies. Haemostasis 1999; 29(4): 197203.

[25] Martinelli I, de Stefano V, Taioli E, Paciaroni K, Rossi E, Mannucci PM. Inherited thrombophilias and first venous thromboembolism during pregnancy and puerperium. Thromb Haemost 2002; 87: 791-5.

[26] Godoy JMP, Spegiorin LCJF, Dallaqua J, Carvalho CFC, Costa IL. Gestation in patients with high levels of anticardiolipin antibodies, a history of deep venous thrombosis and miscarriages. Arch Med Sci 2006; 23: 205-7.

[27] Galli M, Barbui T. Antiphospholipid antibodies and pregnancy. Best Pract Res Clin Haematol 2003; 16(2): 211-25.

[28] Spegiorin LCJF, Godoy JMP, Oliani AH. Evaluation of prophylaxis using low doses of heparin associated with aspirin in pregnancy with multiple miscarriages and high antiphospholipid antibody levels. Arch Med Sci 2007; 3: 43-45.

[29] Godoy JMP, Spergiorin LC, Gallaqua J, de Carvalho CF, Costa IL. Repeated miscarriages in a patient with a high level of anticardiolipin antibodies and myocardial infarction. Prague Med Rep 2006; 107(4): 443-6.

Received: March 24, 2010

(C) Spegiorin et al.; Licensee Bentham Open.

This is an open access article licensed under the terms of the Creative Commons Attribution Non-Commercial License (http://creativecommons.org/licenses/by-nc/ 3.0/) which permits unrestricted, non-commercial use, distribution and reproduction in any medium, provided the work is properly cited. 